DOI No: http://dx.doi.org/10.29228/Joh.54102 Authenticity process is conducted by

Makale Türü: Araştırma makalesi

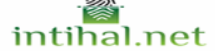

Geliş Tarihi: 07-11-2021

Kabul Tarihi: $13-12-2021$

On-line Yayın: 30-12-2021

Article Type: Research article Submitted: 07-11-2021 Accepted: 13-12-2021

Published Online: 30-12-2021

Attf Bilgisi / Reference Information

Çoban, M. (2021). Various Representations of Bulgarian Characters in Turkish Films and Television Series: A Sociological Analysis. Journal of History School, 55, 4198-4218.

\title{
VARIOUS REPRESENTATIONS OF BULGARIAN CHARACTERS IN TURKISH FILMS AND TELEVISION SERIES: A SOCIOLOGICAL ANALYSIS
}

\author{
Melih ÇOBAN ${ }^{1}$
}

\begin{abstract}
Cinematic works like movies and television series include various social representations. These representations may emanate from political, cultural, social, economic and historical sources. A type of social representation common in cinematic products is the portrayal of members of different ethnic and/or national groups through various character typologies. One of the national groups represented in Turkish cinema is Bulgarians whom Turks have encountered for centuries. In this respect, this study aims to analyse various representations of Bulgarians in Turkish movies and television series in the light of various historical, political and social factors. To this aim, ten films and five television series produced between 1954 and 2019 have been studied. The study is based on two main research problematics: in which periods and under what conditions these cinematic works were produced and through which character categories Bulgarians were portrayed. It has been observed that these cinematic works have been produced, following the initiation of mistreatments by the Bulgarian state of her Turkish minority, with this theme and other themes like the Macedonian issue and that while characters representing the Bulgarian state have mostly been portrayed as villains, civilian Bulgarians have mostly
\end{abstract}

\footnotetext{
${ }^{1}$ Asst. Prof. Dr., Marmara University, Faculty of Arts and Sciences, Department of Sociology, Subdepartment of General Sociology and Methodology, mcoban@marmara.edu.tr, Orcid: 0000-0002$3587-6833$
} 
Various Representations of Bulgarian Characters in Turkish Films...

been described as friendly characters. Same themes and characters have been adapted in the period of normalisation between two countries in a traditionalised way.

Keywords: Turkish Cinema, Bulgarians, Representation, Film, Television Series

\section{Türk Film ve Televizyon Dizilerinde Bulgar Karakterlerin Farklı Temsilleri: Sosyolojik bir Analiz}

\section{Öz}

Filmler ve televizyon dizileri gibi sinematik ürünler pek çok toplumsal temsili içlerinde barındırır. $\mathrm{Bu}$ temsiller, siyasi, sosyal, kültürel, ekonomik ve tarihi kaynaklardan beslenebilmektedir. Sinematik ürünlerde sıkça rastlanılan bir toplumsal temsil türü, farklı etnik ve/veya ulusal topluluklara mensup bireylerin çeşitli karakter tiplemeleri üzerinden betimlenmesidir. Türk sinemasında temsillerine rastlanan ulusal topluluklardan birisi de Türklerin yüzyıllardır ilişki içinde olduğu Bulgarlardır. Bu bağlamda bu araştırmanın amacı, Türk sineması ve televizyon dizilerinde Bulgarların farklı temsillerini çeşitli tarihi, siyasi ve sosyal faktörlerin 1şığında incelemektir. Bu açıdan, 1954 ve 2019 seneleri arasında çekilmiş on film ve beş televizyon dizisi incelenmiştir. Çalışma, Türk sinemasında Bulgar karakterler içeren sinematik ürünlerin hangi dönemlerde ve hangi koşullar 1şığında çekildiği ve Bulgarların hangi karakter kategorileri üzerinden temsil edildiği şeklinde iki temel araştırma sorusuna dayanmaktadır. Bulgaristan'daki Türk azınlığına yönelik kötü muamelelerin başlamasını takiben söz konusu sinematik çalışmaların bu tema ve Makedonya sorunu gibi bir tarihi tema çerçevesinde yapıldığı ve Bulgaristan devletini temsil eden karakterlerin genelde düşman, Bulgar sivillerin ise iyi karakterler olarak gösterildiği gözlenmiştir. Aynı temaların ve karakter temsillerinin kullanımı, iki ülke arası ilişkilerin normalleştiği yıllarda da geleneksel bir şekilde devam etmiştir.

Anahtar kelimeler: Türk Sineması, Bulgarlar, Temsil, Film, Televizyon Dizileri

\section{INTRODUCTION}

Cinema, both an art form and a means of entertainment, has a significant place in people's cultural life. Since the birth of cinema at the end of the 19th century, cinematic products have attracted huge masses worldwide. In today's world, the popularity of these products has still been increasing in relation to the advancements in both cinematic technologies such as the integration of softwarebased visual and audio effects and digital technologies, which increase people's 
access to cinematic products such as DVDs, blue-ray discs and online digital platforms for watching them.

Apart from its global popularity, cinema has deeply influenced the masses. In a social context, this influence takes place on a secondary level which does not include any direct communication with the social reality, but the reflection of this reality on the screen (Monaco, 2000, p.261). The reflection of social reality here refers to the cinematic representation of various social phenomena like social classes, gender relations, social inequalities, social groups, ethnic and religious identities, a political regime, etc. The way these phenomena are represented is a crucial matter in that the audience may become inclined to regard it as reality.

One of these social phenomena referred to in many movies worldwide is the representation of ethnic, religious or national groups. Cinematic products like films and television series have become powerful means of influencing people's thoughts and attitudes about and images of other societies and locations (Busby and Klug, 2001, p.317). In this respect, in the absence of direct communication, an individual may develop either positive or negative reactions towards a certain ethnic or national group based on how the members of that particular group have been portrayed on the screen. These representations may even lead to stereotypes defining a certain ethnic, religious or national group. For instance, Shaheen (2006) in his study, revealed that, in a sample consisting of nearly 1.000 Hollywood movies with Arabic characters, a serious majority of these films had depicted Arabs with negative images and stereotypes and this situation was based on certain historical, cultural, economic and political backgrounds.

Following the rise of cinema in Western Europe and USA at the beginning of the 20th century, a cinema sector also developed in Turkey with its authentic plots, film movements and director schools. In various Turkish movies, peoples of different ethnicities and nationalities have been represented as movie characters such as ethnic minorities like the Jews, Armenians and Greeks in Turkey, and nationalities like Germans, Americans and Russians. Bulgarians were among these national groups who have also been portrayed under different characters in various movies. Considering the centuries-long encounters of the Turkish and Bulgarian people and the relations between Turkey and Bulgaria as two neighboring countries, this study aims to analyse the social, historical and political bases of the various representations of Bulgarian people in Turkish cinematic products. 
Various Representations of Bulgarian Characters in Turkish Films...

\section{METHOD}

In this qualitative study, sociological film analysis has been used. Sociological film analysis, or critique, is important to analyze the relationship between cinema and society. This relationship advances on a mutual level whereas social conditions and phenomena influence and become subjects of cinematic works. On the other hand, cinematic works influence society to change their opinions, attitudes and judgments. In studies involving sociological film analysis, or in broader terms, in film sociology which uses this technique, there are the consequences of movies for society and the study of the consequences of society for the movies studied as the main research problematic (Tudor, 2014, p.152). In this study, the latter level of the relationship between cinema and society, which is the consequences of society for cinema, has been handled.

In this study, the social factors that influence cinema are the foci of analysis. Social factors mean a bundle of historical, political and cultural ones that played an important role in producing Turkish movies and television series with Bulgarian character representations. A historical perspective is needed because sociological film analysis requires the interpretation of cinematic products in accordance with the social conditions prevailing during the period when they were produced or the period they were narrated.

In this respect, this study involves two interrelated foci of analysis. First, the influence of social factors on the production of cinematic works including, Bulgarian characters, has been handled. Secondly, basic character typologies of Bulgarians represented in these works have been categorised. In addition to a review of academic literature, this study has used a sample consisting of ten Turkish films and five television series with Bulgarian characters. These cinematic products have been selected through purposive sampling by using keyword searches on three digital platforms, namely Youtube, Google and TSA (Center for Turkish Cinema Studies). The sample list has been presented in the table below: 
Melih ÇOBAN

Table 1

List of Cinematic Works in the Sample

\begin{tabular}{lll}
\hline Title & Year & Director \\
\hline Bulgar Sadık (Sadık of Bulgaria) & 1954 & Lütfi Ömer Akad \\
Senede Bir Gün (Once Every Year) & 1966 & Ertem Eğilmez \\
Tel Örgü (Wire Netting) & 1969 & Sirrı Gültekin \\
Senede Bir Gün (Once Every Year) & 1971 & Ertem Eğilmez \\
Görevimiz Tehlike (Mission Impossible) & 1972 & Yavuz Figenli \\
Vahşi Bir Kız Sevdim (I loved A Wild Girl) & 1972 & Nejat Saydam \\
Soykırım: Bulgar Zulmü (Genocide: Bulgarian & 1985 & Remzi Jöntürk \\
Oppression & & \\
Değirmen (The Mill) & 1986 & Atıf Yılmaz \\
Yeniden Doğmak (Being Reborn) & 1987 & Osman F. Seden \\
Belene (Belene) & 1989 & Hüseyin Karakaş \\
Elveda Rumeli (Farewell to Rumeli) & $2007-2009$ & Serdar Akar \\
Son Yaz: Balkanlar 1912 (Last Summer: & 2012 & Doğan Ümit Karaca \\
Balkans 1912) & & \\
Kaçış 1950 (Getaway 1950) & 2014 & İbrahim Biçer \\
Çukur (The Pit) & $2017-2021$ & Sinan Öztürk \\
Cep Herkülü: Naim Süleymanoğlu (Little & 2019 & Özer Feyzioğlu \\
Hercules: Naim Süleymanoğlu) & & \\
\hline
\end{tabular}

All elements in the sample have been accessed through digital sources and watched in the home environment.

The limitation of the present study is that not all Turkish movies involving Bulgarian characters could be accessed. These movies understudy could not be accessed through either digital or analog sources. Still, some have been referred to in the study based on written resources on Turkish cinema. The list of these films which had to be excluded from the sample is shown in Table 2 below:

\section{Table 2}

Movies Excluded from the Sample

\begin{tabular}{lll}
\hline Title & Year & Director \\
\hline Senede Bir Gün (Once Every Year) & 1946 & Ferdi Tayfur \\
Demir Perde (Iron Curtain) & 1951 & Semih Evin \\
Hürriyet Şarkısı (Song of Freedom) & 1951 & Faruk Kenç \\
Altı Ölü Var: İpsala Cinayeti (Six Dead: The Ipsala Murder) & 1953 & Lütfi Ömer Akad \\
Vahşi Bir Kız Sevdim (I Loved A Wild Girl) & 1954 & Lütfi Ömer Akad \\
Zulüm Treni (Train of Oppression) & 1989 & Oğuz Gözen \\
Göç Yolu: Elveda Balkanlar (Migration Route: Farewell to the & 2016 & Turgut Ural \\
Balkans) & & \\
\hline
\end{tabular}


Various Representations of Bulgarian Characters in Turkish Films...

\section{FINDINGS AND INTERPRETATION}

The findings of this study have been presented under two categories whereby first, the influence of Turkish-Bulgarian encounters on cinematic works, and second, main character categories represented in these works have been analysed.

\section{Turkish-Bulgarian Encounters and Its Reflections on Turkish Cinema}

The history of Turkish and Bulgarian encounters dates back to over five centuries ago. After the defeat of the Bulgarian army by the Ottomans in 1396, the region covering contemporary Bulgaria fell under Ottoman rule, and Muslim Turks began to settle in the region due to the Ottoman settlement policy (Bishku, 2003, p.77). As was the case with other non-muslim ethnic/religious groups within the Ottoman society, the Bulgarians enjoyed religious freedom and they paid a special tax in return. Ottoman official model of social organization namely the millet (nation) system divided the Ottoman society into various groups based on religious varieties. In this respect, ethnic/religious groups like the Muslim, Orthodox, Jewish and Armenian nations were recognized as the main categories within this system and each group was treated differently in issues like religious organizaton, treatment before the law, taxation and providing communitarian services. In this sense, Bulgarians were placed under the Orthodox nation which was actually dominated by Greek Orthodox elements who constituted the largest group within the non-muslim population of the empire. During the process after the declaration of the Edict of Reforms, which recognized all Ottoman subjects equal before the laws regardless of their religious identities, the millet system fell into desuetude and the Bulgarians were separated from the Orthodox patriarchate and granted their own church in 1871 (Ortayl1, 1987, p.208).

The wave of nationalism that spread through Europe following the French revolution in 1789 attracted the Christian communities in the Ottoman-dominated Balkans and Bulgarians were among these groups who sought independence. Following the Russo-Ottoman War of 1877-78, an autonomous Bulgarian princedom was established (Güner, 1999, p.119). This princedom became fully independent in 1908 and was turned in to the Bulgarian Kingdom. Bulgarians and Ottomans fought against each other during the Balkan Wars in 1912-13 and became allies during the First World War (1914-1918). Following the downfall of the Ottoman Empire and the foundation of the Turkish Republic in 1923, two neighboring countries entered into a new era of mutual relationships, although with some ups and downs. 
The relations between the two countries following the establishment of republican Turkey in 1923 began with good faith and two states signed a treaty of friendship in 1925 (Bishku, 2003, p.80). Following the abolition of the monarchy and the establishment of the socialist regime in Bulgaria in 1946, mutual relations between two states became oriented by two primary factors namely cold war conditions and the treatment of the Turkish minority in Bulgaria. As Turkey and Bulgaria joined opposite camps during the cold war era, diplomatic and economic relations between the two countries remained very low (Coşkun, 2001a, p.1). The mistreatment of the Turkish minority in Bulgaria by the Bulgarian state authorities which aimed to create a culturally homogeneous Bulgarian nation during the cold war era escalated from time to time and raised the tension between the two countries, and became the primary focus of political and diplomatic relations between them. In this sense, the first serious confrontation between two states took place between 1950 and 1951 whereby the Bulgarian state initiated a mandatory migration of 250.000 Turks residing in Bulgaria to Turkey (Şimşir, 1986, pp.212-213). Even though this problem seemed to be settled in time, Bulgarian authorities continued their efforts to assimilate the Turkish minority. A new assimilation campaign broke out in the 1980s which revived the tension between the two countries. After the end of the socialist regime in Bulgaria, assimilationist efforts towards the Turkish minority as an official state policy halted. Under the post cold war conditions, relations between the two countries entered into a period of normalisation (Coşkun, 2001a, pp.49$51)$.

The rising tension between the two countries has found its reflection on Turkish cinema in terms of various representations of historical or current events and conditions. Following the end of the Second World War, as Bulgaria became a socialist republic, the first assimilationist state policies toward its ethnic minorities were initiated as early as 1946 (Şimşir, 1986, pp.213-217). It is not surprising to see the influences of these two conditions on Turkish cinema as the first Turkish films portraying Bulgarian characters involved in movie plots concerning Turkish-Bulgarian encounters. In this respect, the first Turkish movie with such content is Senede Bir Gün (1946) ${ }^{2}$ which was based on a novel with the same name by Turkish author İhsan Koza and told the story of two Turkish lovers who tried to escape from Bulgaria to Turkey and one of them, the main hero of the film named Emin, suffered from the cruel treatments of Bulgarian soldiers such as being shot while trying to escape and sent to prison (Özgül, 1974, p.91). Following the events of 1950-51 in Bulgaria, more movies with Bulgarian

\footnotetext{
${ }^{2}$ This is a lost movie which could not be accessed and added to the sample.
} 
characters were produced. Some of these movies had plots based on the TurkishBulgarian encounters in Macedonia, the last Ottoman-ruled region in the Balkans, such as Hürriyet Şarklst (1951) which told the story of Turkish villagers who bravely fought against the Bulgarian bandits who attacked their village (Özgüç, 2012, p.47) and Bulgar Sadlk (1954) which told the story of a Turkish soldier named Sadık who fought against the Bulgarian bandits in Macedonia. The movie titled Vahşi Bir Krz Sevdim (1954) told the story of an Ottoman officer who was sent to Macedonia with the mission of neutralizing a Bulgarian band and his love affair with the female member of this band named Kristina (Özgül, 1974, p.262). Another movie produced in this period titled Demir Perde (1951) was about a young Turkish man and his sister who took revenge from the Bulgarian soldiers who killed their father (Özgül, 1974, p.146). The film was based on the events of 1950-51 and even the title of the movie Demir Perde which means "iron curtain" in Turkish was an emphasis on the negative image of socialist regimes which was very popular among large Turkish masses under cold war conditions as Turkey had sided with the Western Block.

Unlike the tension experienced in the 1950s, the 1960s and 1970s were the decades of relatively more peaceful relations between Turkey and Bulgaria. Between 1964 and 1984, a total of 21 diplomatic visits took place mutually between the two states (Coşkun, 2001a, p.24). Unlike the beginning of the 1950s, Bulgarian state policy towards the Turkish minority did not involve harsh treatments. During this period, four Turkish including Bulgarian characters were produced. Two of them were the remakes of Senede Bir Gün (1946) were produced with the same title and plot in 1966 and 1971. Another remake of Vahşi Bir Krz Sevdim (1954) was shot in 1972 with the same title and plot as well. The movie Tel Örgü (1969) was about two Turkish men who escaped to Turkey from Bulgarian oppression, a plot based on the 1950-51 events.

The year 1984 was an important turning point in Turkish-Bulgarian relations and the representation of Bulgarian characters in Turkish films. The ideal of a culturally homogeneous Bulgarian nation was revived in 1982 by the Bulgarian government under a new assimilationist program that aimed to integrate all ethnic and religious minorities into a Bulgarian identity (Şimşir, 1986, p.339). This program became effective as of 1984, whereby certain official regulations such as restricting religious practices and making the Bulgarian language mandatory in public places were executed. Such assimilationist measures did apply to the Turkish minority and other minority groups like the Pomaks, Roma and Albanians. Turks, constituting the largest ethnic minority, posed the biggest threat to the cultural and ethnic unity of Bulgarian society in the eyes of the state authorities. At the beginning of the 1980s, it was assumed 
that ethnic Turks in Bulgaria had a population ranging between 900.000 to 1.500 .000 which constituted more than $\% 10$ percent of the total population in Bulgaria (Coşkun, 2001a, p.22).

The assimilation campaign met massive reaction by the Turkish minority when an official decree forced them to change their Turkish names and surnames to Bulgarian ones. In December 1984, when a group of ethnic Turks gathered in the Kurcali region to protest the mandatory name change program, Bulgarian soldiers opened fire on the crowd and the protest and seven people were killed, and many were injured (Zafer, 2010, p.28). Those who refused to change their names were arrested and sent to prison and work camps like the infamous Belene Camp or mines like Bobol Dov, or exiled to other districts in Bulgaria. The requests of many ethnic Turks to migrate to Turkey were denied by the Bulgarian authorities (Dayığlu, 2005, p.343).

The news of the assimilation campaign turned into an important agenda of the Turkish public opinion and Turkish media began to focus on the tragic news concerning the misery of many ethnic Turks in Bulgaria. Against rising social tension among the Turkish society, the Turkish government became involved in the situation, and a series of diplomatic memorandum was issued asking the Bulgarian government to end this mistreatment of Turks immediately (Coşkun, 2001a, p.25). This situation continued until the end of 1989 when Bulgarian prime-minister Todor Jivkov resigned from his post and an official decree halted the assimilation campaign (Coşkun, 2001b, p.29).

The assimilation period between 1984 and 1989 and the reactions by the Turkish public and state have found a serious reflection on the Turkish cinema sector as well. During this period, two films about the oppressions of the Bulgarian government during the campaign, namely Soykirtm: Bulgar Zulmü (1985) and Zulüm Treni (1989) were produced. More significantly, two television series, Yeniden Doğmak (1987) and Belene (1989) aired on Turkish state-owned television channel TRT. Of these two series, especially Yeniden Doğmak raised public interest in the Bulgarian Turks problem since it gained huge public popularity with its plot which was based on a true story. In the series, the plot focused on the tragedy of three Turkish families who tried to migrate to Turkey to escape Bulgarian oppression. One family was trying to unite with their daughter Aysel who was left after their escape behind in Bulgaria. The real story of this separated family and the hostage status of Aysel who was not permitted to unite with her family led to a serious public tension in Turkey to such a level that the series became an issue of the political bargain between Bulgarian and Turkish governments. Turkish and Bulgarian governments reached an agreement that 
Aysel was released and sent to Turkey to unite with her family in return for the TRT channel to stop airing the series (Çokum, n.d.).

After the end of the assimilation campaign and the end of the socialist regime in Bulgaria, mutual relations between Turkey and Bulgaria began to normalise. This situation has been continuing since the beginning of the 1990s and no serious problem concerning the Turkish minority in Bulgaria has taken place in this period so far. But, Bulgarian characters continued to be portrayed in other following Turkish movies and television series. In this period, three films namely Kaçış 1950 (2014), Göç Yolu (2016) and Cep Herkülü: Naim Süleymanoğlu (2019) and two television series, Elveda Rumeli (2007-2009) and Son Yaz Balkanlar 1912 (2012) with plots concerning historical problems experienced by Turks and in this respect, their encounters with Bulgarians have been produced. This situation can be linked to the fact that, since the beginning of the 2000s, many Turkish producers have focused on new cinema and television projects with historical and biographical plots and the misery of Turks in Ottoman Macedonia and Republican Bulgaria have been one of the plots to be handled.

\section{Representations of Bulgarian Characters}

While reflecting historical, social and/or political issues on the screen, one of the most significant elements which emphasize these issues within the plot is the portrayal of characters. Sociologically speaking, characters may symbolize or represent a value, ideology, social group, social class or a social problem. In portraying Bulgarian characters in Turkish movies and television series, it is possible to conclude various character categories all of which have a historical and social background in the plot. All Bulgarian characters represented in the sample have been shown in table 3 below:

\section{Table 3}

Bulgarian Characters in the Sample

\begin{tabular}{lcl}
\hline Title & Year & Bulgarian Characters \\
\hline $\begin{array}{l}\text { Bulgar Sadık } \\
\text { (Sadık of }\end{array}$ & 1954 & $\begin{array}{l}\text { Boris Daskalov (bandit), Sandanevsky (head of the } \\
\text { Bulgarian committee), unnamed members of the } \\
\text { Bulgaria) }\end{array}$ \\
$\begin{array}{l}\text { Senede Bir Gün } \\
\text { (Once Every }\end{array}$ & 1966 & $\begin{array}{l}\text { unnamed Bulgarian soldiers } \\
\text { unnamed Bulgarian soldiers }\end{array}$ \\
Year) & &
\end{tabular}




\section{Melih ÇOBAN}

Tel Örgü (Wire

Netting)

Senede Bir Gün

(Once Every

Year)

Görevimiz

Tehlike (Mission

Impossible)

Vahşi Bir Kız

Sevdim (I loved A

Wild Girl)

Soykırım: Bulgar

Zulmü (Genocide:

Bulgarian

Oppression)

Değirmen (The

Mill)

Yeniden Doğmak

(Being Reborn)

Belene (Belene)
1969 Unnamed Bulgarian soldiers, unnamed old Bulgarian woman, unnamed Bulgarian villagers

1971 Kiril (commander), unnamed Bulgarian soldiers

1972 Unnamed Bulgarian soldiers, unnamed old Bulgarian lady, unnamed Bulgarian bandits

1972 Kristina (bandit), Nikola (bandit), Ivan (bandit), Yorgi (bandit), unnamed Bulgarian bandits

1985 Svetlana (soldier), Boris (commander), Ivan Kospotin (Communist Party officer), Sergei Antuanov (commander), unnamed Bulgarian soldiers

1986 Nadja (civilian)

1987 unnamed Bulgarian soldiers, Peter the mailman, Olga (civilian), Eva (doctor), Pantev, (commander)

1989 Erika (civilian), unnamed school principal, Theodor (little boy), Giorgi (Communist party officer), Mihail (Doctor), unnamed Bulgarian soldiers, Yuri (director), unnamed Bulgarian interrogator, unnamed old Bulgarian man, unnamed Bulgarian couple

Elveda Rumeli

2007- Dimitri (bandit), Yorgi the Black (bandit), Ivan

(Farewell to

Rumeli)

Son Yaz:

Balkanlar 1912

(Last Summer:

Balkans 1912)

Kaçış 1950

(Getaway 1950)

Çukur (The Pit)

2017

2021

(doctor), Nikola (tailor), unnamed Bulgarian bandits

2012 Ivan (bandit), unnamed Bulgarian bandits, Vasil (villager), Vasil's sister (villager), Aleksi (businessman), unnamed Bulgarian priest, unnamed Bulgarian commander, unnamed Bulgarian group of young men

2014 Unnamed school principal, unnamed Bulgarian commander, unnamed Bulgarian soldiers, Svetlana (civilian)

unnamed Bulgarian gangsters, unnamed Bulgarian smugglers

Cep Herkülü: N. 2019 Ivan the trainer, unnamed Bulgarian soldiers, Sylvia

Süleymanoğlu

(Little Hercules: (little girl), Todor Jivkov (Bulgarian prime minister), unnamed Agents of the Bulgarian Communist Party

N. Süleymanoğlu) 
Various Representations of Bulgarian Characters in Turkish Films...

The basic character categories in this sense can be analysed as follows:

\section{The Komitadji (Komitacl) Bulgarian}

The komitadji ${ }^{3}$ Bulgarians are characters visible in Turkish movies or television series of plots evolving around the Macedonian question during the late 19th and early 20th century Ottoman Macedonia. The ultimate goal of the $19^{\text {th }}$ century Bulgarian nationalist movement was to create a Great Bulgaria under which all Bulgarian people would be united. After the Berlin Congress of 1878, while an autonomous Bulgarian princedom was established, Ottoman rule over Macedonia was maintained. With its ethnically heterogeneous population, Macedonia was a significant region for Balkan kingdoms like Bulgaria, Greece and Serbia. Ottomans lost their control over the area after the Balkan Wars and Macedonia was divided among these three kingdoms in 1913 (Bishku, 2003, pp.78-79).

In the last quarter of the 19th century, Macedonia was inhabited by various ethnic groups such as Turks, Albanians, Bulgarians, Serbians, Greeks and Vlachs (Altıntaş, 2005, p.72). Other than the Turks, there was competition among these ethnic groups to take control of Macedonia. The Ottoman authority in the region and the settled Turkish population was their common enemy (Aydın, 2019, p.1593). Therefore, each ethnic group began to form their militia groups in the form of armed bands to increase their dominance in the region and gain independence from the Ottomans. These militia groups were organized and controlled by committees consisting of civilians who acted as the brains of these independence movements. These committees and their armed extensions together were named as komitadji (Aydın, 2019, p.1590). Bulgarians were the most powerful among all the komitadji organizations in Macedonia, considering the number of armed bands they possessed. Before 1908, there were 110 Bulgarian, 80 Greek, 30 Serbian and 5 Vlach militia groups operating in the region (Çanl1, 2017, p.2829). In addition, Bulgarians were systematically organized in Macedonia when compared to other komitadji groups, and their activities were directly controlled and supported by a central body located in Sofia (Akbal, 2011, p.72).

The main goal of the komitadji organizations was to create chaos in Macedonia through armed attacks and thus enable the intervention of the great European Powers into the Macedonian question to their advantage (Çanl1, 2017, p.2833). In doing so, Bulgarian, Greek and Serbian komitadji groups aimed to

\footnotetext{
${ }^{3}$ Komitadji is a term, originally komitace in Turkish, which refers to a person who is a member of and works for a committee in Ottoman Macedonia.
} 
join Macedonia with their motherlands. While also competing with each other, they primarily focused on the Turkish population in Macedonia and aimed to change the ethnodemographic balance of the region to their advantage by deterring the Turkish residents through acts of terror and forcing them to migrate (Akbal, 2011, p.71). Their terror first began with armed attacks on Ottoman officers posted in Macedonia and later on evolved with attacks on Turkish villages, inflicting physical damage to both the villagers and their material possessions such as houses and plantations (Aydin, 2019, pp.1598-1599).

The violent actions of the komitadji bands against the Turkish residents of Macedonia continued until the end of the Balkan Wars after which Macedonia was lost to the victorious parties and it longer remained as Ottoman land. A large majority of the Turkish residents migrated to the lands under the Ottoman rule to seek refuge. The sufferings of the Turks in Macedonia remained alive in the collective memory of the Turkish society since there is a considerable Turkish population of Macedonian origin. In addition to the oral history transmitted from generation to generation, cultural products like novels, films and television series also contributed to this situation.

The first komitadji characters in Turkish cinema are found in Bulgar Sadık (1954). The film includes the characters Boris Daskalov, a notorious bandit who is the leader of a Bulgarian komitadji gang and Sandanevsky, the leader of the Bulgarian committee. Both characters are cruel, attracted to violence and aim to annex Macedonia to Bulgaria at all costs. Daskalov and Sandanevsky represent the typical hierarchy common in all komitadji groups. In contrast, Daskalov and his gang constitute the muscles under the commands of Sandanevsky who is the brains of the organization. There are scenes in the movie which strengthen the negative image of the komitadji characters such as Sandenevsky giving his orders to Daskalov by saying "Kill all the Turks, kill them all! Burn down their villages!" and members of the Bulgarian committee forcing a Turkish girl to dance for them and humiliating her with this forced action.

A similar representation of komitadji characters is also found in Vahşi Bir Klz Sevdim (1972). This time, the brain team of the organization is not mentioned, but only the members of the Bulgarian gang who attack Turkish villages and Ottoman officers are portrayed. The gang leader, Nikola, and his men, especially his sidekicks Ivan and Yorgi are cruel and violent men who fit the popular komitadji image. Raised by her father like a boy, Nikola's daughter Kristina is also a gang member. However, she is a good person in heart and she falls in love with Captain Adil of the Ottoman army who was assigned to eliminate Nikola's gang and she even converts to Islam in the name of love. 
Similar komitadji typologies were adapted in two television series namely Elveda Rumeli (2007-2009) and Son Yaz Balkanlar 1912 (2012) as well. In Elveda Rumeli, there is a Bulgarian gang of cruel bandits led by Dimitri and his second in command Yorgi the Black. The brain team who command this gang is represented by two Bulgarian civilians namely Dr. Ivan and Nikola the tailor. In Son Yaz Balkanlar 1912, a series that stopped airing after four episodes, a gang led by a vicious man named Ivan aim to deter Turkish villagers through physical assaults and threats and force them to leave their lands to migrate. The lands left by the Turks are to be bought for very cheap prices by the brain team of the organization led by a middle-class Bulgarian named Aleksi.

In these four exemplifying productions, komitadji organizations' brains and muscles have been depicted as cruel, violent, and hostile characters and they fit with other depictions of the komitadji in historical and narrative sources. It can be said that a komitadji stereotype with negative characteristics has been developed in Turkish cinematic narration. The only exceptional case in this context is the Kristina character in Vahşi Bir Kız Sevdim (1972) who switches from villain to heroine status by cooperating and falling in love with the protagonist and even going further to convert from Christendom to Islam, a development in the flow of cinematic narration which is seen in various Turkish movies $^{4}$.

\section{Bulgarian State Officers}

Bulgarian characters employed in the public sector and serving as state officers constitute the largest category of characters in number. They consist of people with various professions and positions in the military and civilian state bureaucracy such as army officers, soldiers, doctors, school principals and the Bulgarian Communist Party representatives. Their basic function is to represent the state power with their positions and roles. In the films and television series in the sample of this study, most of these characters have been portrayed as villains; however, a minority of them has been depicted as friendly or neutral towards the Turks. In all cinematic productions within the sample, Bulgarian soldiers have been portrayed as villains who follow the direct orders of their superiors without any question and mistreat, torture and even kill Turkish civilians. The only exception to this situation is the character in the movie Soykırım: Bulgar Zulmü (1985) named Svetlana, a Bulgarian soldier in love with the hero named Destan,

\footnotetext{
${ }^{4}$ Various examples of this situation can be seen in Turkish movies like the Kara Murat film series (1972-1978).
} 
a Turkish man who is secretly protecting the Turkish villagers against the oppression of the Bulgarian soldiers. Svetlana is a good person who is deeply in love with Destan and converts to Islam, a case similar to the Kristina character in Vahşi Bir Kız Sevdim (1972).

Bulgarian army officers constitute another group within this character category. They are all portrayed as evil characters who show no sympathy or mercy towards the Turks and express their anti-Turk opinions in many lines in the script. In movies with plots during the socialist era in Bulgaria, army officers, through their lines expressing their loyalty to the socialist regime, have been used as elements that stress the state power and control over the citizens, a significant characteristic of totalitarianism. The only semi-exceptional case in this context is Commander Boris in Soykırım: Bulgar Zulmü (1985) who treats the Turkish villagers cruelly, but upon seeing his Turkish friend Alay Bey, who is a respected member of the Communist Party, shot by Bulgarian soldiers under the command of another officer, he reacts to this situation and gets shot and killed by the other officer.

Bulgarian soldiers and army officers symbolize state power and oppression against the Turks. Their actions reflect Bulgarian state policies towards the Turkish minority in 1950-51 and 1984-89. It is not surprising to see those characters as villains in terms of cinematic representation. Speaking of other state officers within the civilian bureaucracy portrayed in the sample, their images have a relatively positive characteristic considering their attitudes towards Turks. For instance, while the Bulgarian school principal in Kaçıs 1950 (2014) is a villain who treats a Turkish student very harshly, the school principal in the television series Belene (1989) is a good person who treats the Turkish students and teachers at his school in a friendly and non-discriminative manner. Low rank state officers such as Dr. Eva and Peter the postman in Yeniden Doğmak (1987) and Dr. Mihail in Belene (1989) have been depicted as friendly and helpful people who do not refrain from establishing close relations with Turks. The situation of Dr. Eva constitutes a unique example in that she secretly continues to examine Turkish patients even though she was threatened by Commander Pantev, the main villain of the series, such that if she continued to examine Turkish patients who could not speak Bulgarian, she could be killed. Sevinç Çokum, the scriptwriter of Yeniden Doğmak explained this situation by stating that mistreatments by some could not be attributed to a whole nation. Therefore, those Bulgarians in real life who did not approve of such mistreatments of Turks should be portrayed through these characters (Çokum, n.d.). 
Various Representations of Bulgarian Characters in Turkish Films...

\section{Bulgarian Civilians}

In Turkish movies and television series in the sample of this study, apart from characters with anti-Turk objectives such as the komitadji or characters who represent the Bulgarian state bureaucracy, Bulgarian civilians have also been portrayed. While most of these characters are people with friendly attitudes towards the Turks, some of them present hostile attitudes. In Belene (1989), all civilian characters namely Erika, Theodor, the old Bulgarian couple and old Bulgarian villager are friendly towards the Turks and do not approve of the mistreatments by the Bulgarian government. The same situation applies to other cinematic representations like Sylvia in Cep Herkülü: Naim Süleymanoğlu (2019), a Bulgarian primary schoolgirl who is a close friend of Naim, the main hero, and whose parents were sent to exile because of establishing close relations with Turks and Dr. Mihail's wife Olga in Yeniden Doğmak (1987) who is very fond of her Turkish neighbors. A mixed type of portrayal takes place in Son Yaz Balkanlar 1912 (2012) whereas Vasil, a Bulgarian villager who is a close friend of his Turkish neighbors, can not resist the offers by the komitadji leader Ivan to join them and he burns down the storehouse of his Turkish neighbors. Vasil's sister, unlike his brother, is very fond of her good relations with the Turks. Another friendly character is the Bulgarian priest. When the committee member Aleksi asks him to preach to the Bulgarian community to raise their nationalist sentiments, he refuses to do so by stating that he can not urge people to act against their brothers.

A civilian character whose portrayal has no link with the historical and political context concerning Turkish-Bulgarian relations is Nadja in the movie Degirmen (1986). In the movie, Nadja, also known as Naciye, is a Bulgarian prostitute in an Ottoman town who uses her charm to enchant the Ottoman town governor in order to escape persecution for the crime of prostitution. This character has likely been portrayed in the movie to emphasize the multi-ethnic structure of Ottoman society and therefore seems to constitute an alternative portrayal out of the main context in this study.

\section{Bulgarian Mafia}

Another alternative representation of Bulgarian characters is the Bulgarian mafia which has no link with the historical and political context concerning the cinematic portrayal of Bulgarian characters. Still, this representation is based on a social reality. The close relations between Turkish and Bulgarian criminal organizations date back to the beginning of the 1980s especially in establishing a 
partnership in illegal arms and technological device smuggling (Mumcu, 1993, pp.108-112). During the 1980s, various notable Turkish mafia leaders were invited to Sofia to hold meetings with the Bulgarian mafia bosses and develop further cooperation (Yurdakul, 2002, pp.310-311).

Even though the relations between Bulgarian and Turkish mafia groups have a long history, the Bulgarian mafia had operated within their national frontiers. In the Turkish television series Çukur (2017-2021), there are two representations of Bulgarian organizations involved in illegal sectors: the Bulgarian smugglers at the Turkish-Bulgarian border area and the Bulgarian mafia group in Istanbul. The Bulgarian smugglers betray their Turkish partners whereas the other Bulgarian mafia group is so violent and frightening that they even pour the cut heads of dozens of lambs on the residence of their Turkish partners to scare them. Similar portrayals of cold-blooded brutality have been used in various Hollywood movies while depicting the Russian mafia ${ }^{5}$ and this pattern has been used in Çukur as well. The operations of Bulgarian mafia groups in Istanbul in the series are based on truth such that the infamous Bulgarian mafia boss Dimitar Zhelyazkov was arrested in Istanbul in 2018 and extradited to Bulgaria (Bulgarian mafia boss arrested in Istanbul, 2018).

\section{DISCUSSION, CONCLUSION AND RECOMMENDATIONS}

The findings of this study put forward two interrelated contexts. First, within the context of social and historical factors and their reflections on cinematic works, it has been the case in Turkish films and television series that they began to include Bulgarian characters since the beginning of a complex process between two countries emanating from the mistreatments of the Turkish minority by the Bulgarian state. Secondly, the Bulgarian characters portrayed in these works were inspired by historical and political phenomena like the Bulgarian komitadji activities in Ottoman Macedonia and the assimilationist policies of the Bulgarian state towards her Turkish minority in the republican era. These portrayals mostly placed characters who symbolised the Bulgarian state as villains, whereas civilian Bulgarians were mostly depicted as friendly characters.

Since the beginning of the 2000s, even though there has been no problem between Turkey and Bulgaria related to the Turkish minority or any other issue, various films and television series with similar plots and character typologies have been produced. This situation seems to put limitations on Turkish cinematic

5 The Russian mafia stereotype can be seen in various Hollywood movies like Eastern Promises (2007), Training Day (2001), John Wick (2014) and Nobody (2021).

[4214] 
representations concerning the changing political and social conditions such that Turkish-Bulgarian relations have entered a normalisation phase since the beginning of the $90 \mathrm{~s}$ and that Turks in Bulgaria have been enjoying more freedoms than before and have been integrated into Bulgarian society on a deeper level with many Turks being employed in the state bureaucracy, intermarriages between Bulgarians and Turks and many other kinds of interaction and integration. Therefore, using traditionalised versions of plots and characters concerning Bulgaria and Bulgarians in Turkish cinematic works seem outdated. In this sense, the reflections of these new conditions on new cinematic products would be appropriate regarding the mutual relationship between cinema and society.

\section{REFERENCES}

Akbal, İ. (2011). Komitacı eylemlerin son temsilcisi İsmail Hakkı Tekçe ve faaliyetleri. Cumhuriyet Tarihi Araştırmaları Dergisi, (13), 70-102.

Altıntaş, A. (2005). Makedonya sorunu ve çete faaliyetleri. Afyon Kocatepe Üniversitesi Sosyal Bilimler Dergisi, 7(2), 69-9.

Aydın, M. (2019), Osmanlı Makedonyasında slavist Bulgar komita faaliyetleri. Belgi Dergisi, 2(18), 1587-1606.

Bishku, M. B. (2003). Turkish-Bulgarian relations: From conflict and distrust to cooperation over minority issues and international politics. Mediterranean Quarterly, 14(2), 77-94.

Bulgarian mafia boss arrested in Istanbul (2018, August 5). Hürriyet Daily News, https://www.hurriyetdailynews.com/bulgarian-mafia-boss-arrested-inistanbul-135452.

Busby, G. \& Klug, J. (2001). Movie-induced tourism: The challenge of measurement and other issues. Journal of Vacation Marketing, 7(4), 316332.

Coşkun, B. D. (2001a). Bulgaristan’la Yeni Dönem: Soğuk Savaş Sonrası Ankara-Sofya İlişkileri. Avrasya Stratejik Araştırmalar Merkezi Yayınları.

Coşkun, B. D. (2001b). Turkish-Bulgarian relations in the post-cold war era; The exemplary relationship in the Balkans. The Turkish Yearbook of International Relations, (32), 25-60. 


\section{Melih ÇOBAN}

Çanlı, M. (2017). Balkanlarda komitacılık ve çetecilik: II. Meşrutiyet dönemi meclis-i mebusan oturumlarında yapılan tartışmalar ve çözüm önerileri üzerine bir değerlendirme. Uluslararası Türkçe Edebiyat Kültür Eğitim Dergisi, 6(4), 2825-2846.

Çokum, S. (n.d.). Yeniden Doğmak. http://www.sevinccokum.info/?page_id=440

Dayığlu, A. (2005). Toplama Kampından Meclise - Bulgaristan'da Türk ve Müslüman Azınlığı. Iletişim Yayınları.

Güner, Z. (1999). Milli mücadele döneminde Batı Trakya'da Bulgar zulümleri. Erdem Insan ve Toplum Bilimleri Dergisi, 12(34), 119-128.

Monaco, J. (2000). How to Read a Film: Movies, Media, Multimedia. Oxford University Press.

Mumcu, U. (1993). Papa Mafya Ăgca. Tekin Yayınevi.

Ortaylı, İ. (1987). Imparatorluğun en Uzun Yüzyılı. Hil Yayın.

Özgüç, A. (2012). Ansiklopedik Türk filmleri sözlüğü. Horizon International.

Özgül, Y. (1974). Türk Sinema Filmleri Ansiklopedisi 1914-2010. C.I. 1914-196. https://turuz.com/storage/her_konu-2019-7/6612-Turk_Sinema_Filmleri_ Ansiklopedisi-I-1914-1961-Yalchin_Ozgul-1974-520s.pdf, Erişim tarihì: 14.10.2021.

Shaheen, J. G., (2006). Reel Bad Arabs: How Hollywood Vilifies a People. Media Education Foundation.

Şimşir, B. N. (1985). Bulgaristan Türkleri. Bilgi Yayınevi.

Tudor, A. (2014). Image and Influence: Studies in the Sociology of Film. Routledge.

Yurdakul, D. (2002). Abi: Dündar Kılıç ve Kabadayılık Efsanesi. Umit Yayıncilık.

Zafer, Z. (2010). Bulgaristan Türkleri'nin 1984-1989 eritme politikasına karş1 direnişi. Akademik Bakış, 3(6), 27-44. 
Various Representations of Bulgarian Characters in Turkish Films...

\section{EXTENDED ABSTRACT}

Cinema is a branch of fine arts which does not simply serve as a means of entertainment, but also possesses social functions and significance. Cinematic works like movies and television series include various social representations. These representations may emanate from political, cultural, social, economic and historical sources. A type of social representation which is very common in cinematic products is the portrayal of members of different ethnic and/or national groups through various character typologies. These representations, while being shown through mostly fictional characters, are based on a social and historical background.

In many Turkish cinematic works, representations of characters of various nationalities have been visible. One of these national groups is the Bulgarians with whom Turks have encounters for centuries. In this respect, the aim of this study is to analyse various representations of Bulgarians in Turkish movies and television series in the light of various historical, political and social factors. To this aim, 10 films and 5 television series which have been produced between 1954 and 2019 have been studied. The study is based on two main research problematics: in which periods and under what conditions these cinematic works were produced and through which character categories Bulgarians were portrayed.

The sample analysed in this context put forward that cinematic works in Turkey including Bulgarian characters have been produced, following the initiation of mistreatments by the Bulgarian state of her Turkish minority. Following the establishment of a socialist regime in Bulgaria after the end of the Second World War, Bulgarian political authorities aimed to initiate a cultural assimilation program concerning ethnic and religious minorities in Bulgaria and Turks as of constituting the largest minority group in population became their main target. This assimilation policy which continued with intervals during the Cold War era has led to political crisis between Turkish and Bulgarians ctates and raised public tension among Turkish society as well. In this period, Turkish films were produced with this assimilation theme portraying the mistreatments of Turks by Bulgarian authorities and with another theme, namely the Macedonian problem of the late 1800s and early 1900s in Ottoman Empire which has remained as a significant issue alive in the collective memory of Turkish society.

In terms of character typology, four main character ctaegories can be deducted from the sample. In this respect, the first category is the Komitadji Bulgarian. Komitadji members of organisations called committees founded among various ethnic groups in Ottoman Macedonia consisting of civilians, who acted as the 
brain team and of militia bands who acted as the armed power of the organisation. The committees of each ethnic group aimed to deter the rival ethnic groups through armed assaults and other violent means and in doing so, to change the demographic balances in Macedonia in their own advantage to claim their dominance over the region. Almost all Bulgarian civilian and militia komitadji characters have been portrayed as hostile, violent and ruthless people who mistreated Turks.

A second category is found in cinematic works about Republican Bulgaria era, whereby the assimilationist policies of and mistreatments by the Bulgarian state have been the basic theme. In this respect, Bulgarian state officers employed in either military or civilian bureaucracy, who represent state power and official policy have been portrayed. While characters like Bulgarian soldiers, commanders and representatives of the Communist Party have mostly been portrayed as villains who treat the Turks in a hostile and violent manner, other lower level officers like doctors have been portrayed as friendly people.

A third character category is the Bulgarian civilians who mostly have been portrayed as friendly people with positive attitudes towards Turks. Such characters have been used in order to stress that all members of a nationality should not be regarded as villains based on the actions of the few. A fourth category, the Bulgarian mafia, does not stem from historical or political background, but rather from a social reality that in recent years, Bulgarian mafia groups began to operate in Turkey. This character category therefore remains on an alternative level when compared to other character categories.

Following the end of the 1980s, the relations between two countries entered into a normalisation process, but same themes and characters have been adapted in films and television series of this period in a traditionalised way. It has been recommended that in this new era, instead of using such themes and characters, new social themes concerning the current social situation of Turks in Bulgaria and new Bulgarian characters who would contribute to these themes should be integrated into Turkish cinematic products. 